Sains Malaysiana 49(12)(2020): 3065-3072

http://dx.doi.org/10.17576/jsm-2020-4912-18

\title{
Rapid Prototyping of Micropillars using Digital Light Process 3D Printing Technique
}

(Pemprototip Pantas Tiang Mikro menggunakan Teknik Pencetakan Proses Cahaya Digital 3D)

\author{
Nur Aliyah Alwani Mohd Nazam, Jumril Yunas*, Abdul Hafiz Mat Sulaiman, Muhamad, Ramdzan \\ BUYONG \& AZRUL AZLAN HAMZAH
}

\begin{abstract}
In this paper, we discuss a technique to fabricate a three-dimensional (3D) printed micropillars structure of microfluidic system. The developed system consists of microchannels, chambers, and micropillars. The creation of arrays of pillars were the focus of the study. The structure is fabricated using a 3D printing technique called Digital Light Process $(D L P)$. In this paper, we examine the potential use of the 3D printing approaches for the fabrication of microfilter and micromixer devices integrated with microfluidic channels. Our $3 D$ printing process shows that micropillars with diameters between 200 and $400 \mu \mathrm{m}$ can be fabricated using a DLP 3D printer machine by optimizing the preparation process and post processing parameters. Later, SEM analysis shows that micropillars with high aspect ratio and straight side wall were achieved. The DLP 3D printer is the most suitable and reliable technique that can produce the smallest dimension compared to other types of $3 D$ printer that shows a promising method for the rapid prototyping of microfluidic devices for biomedical application.
\end{abstract}

Keywords: 3D printer; digital light process; microfluidic; microfilter and mixer; micropillars; rapid prototyping

ABSTRAK

Dalam makalah ini kami membincangkan teknik memfabrikasi struktur tiga dimensi (3D) sistem mikrofluida. Sistem yang dibangunkan terdiri daripada saluran mikro, ruang dan tiang mikro. Penciptaan tiang susunan adalah fokus kajian. Struktur tersebut dibuat menggunakan teknik percetakan 3D yang disebut sebagai Proses Cahaya Digital (DLP). Dalam makalah ini, kami meneliti potensi penggunaan pendekatan pencetakan $3 D$ untuk pembuatan peranti turas mikro dan pencampur mikro yang disatukan dengan saluran mikrofluida. Proses pencetakan 3D kami menunjukkan bahawa tiang mikro dengan diameter antara 200 dan $400 \mu \mathrm{m}$ dapat dibuat menggunakan mesin pencetak 3D DLP dengan mengoptimumkan proses penyediaan dan parameter pasca pemprosesan. Kemudian, analisis SEM menunjukkan bahawa tiang mikro dengan nisbah aspek tinggi dan dinding sisi lurus dapat dicapai. Pencetak 3D DLP adalah teknik yang paling sesuai dan dipercayai boleh menghasilkan dimensi terkecil berbanding jenis pencetak $3 D$ yang lain dan menunjukkan kaedah ini yang menjanjikan untuk pemprototaip pantas peranti mikrofluida untuk aplikasi bioperubatan.

Kata kunci: Mikrofluida; penapis mikro dan pengadun; pencetak 3D; proses cahaya digital; tiang mikro

\section{INTRODUCTION}

Over the past few years, the development of 3D printing technique has gain attentions in the biomedical field. Microfluidic system has been the most important part of the biomedical instrumentation to full fill the demand of low sample, low energy consumption and precision sample management (Yilmaz \& Yilmaz 2018). The system consists in general of microchannels, chambers, and some sensors and actuators part, while the microfilter and mixer are the most important parts of the system (Mustafa et al. 2019; Yunas et al. 2020).
The microfiltration is used to remove waste materials such as metabolic wastes and foreign chemicals from blood using membranes that have a moderate retention (Buyong et al. 2015; Yaakub et al. 2018). Recent developments of membranes for sample filtration have greatly extended their capabilities in very high or low $\mathrm{pH}$ environments and in their application to non-aqueous liquids. These membranes tend to have a slightly charged surface, with a negative charge at neutral $\mathrm{pH}$. This surface charge plays an important role in the transportation mechanism and separation properties of the membrane 
(Shaaban et al. 2016). More focused biomedical application is the artificial kidney, in which the filtration membrane is one of vital components assembled in a dialysis machine to allow wastes to be separated out from essential solutes that will be returned to the body during dialysis treatment (Hamzah et al. 2013; Mustafa et al. 2017).

On the other hand, micromixer device is commonly known to mix different solutions or to separate between size of particles (Ali et al. 2017). A micromixer is a device based on mechanical microparts that is used to mix fluids. Micromixers are categorised as passive and active micromixers. For active micromixer, it requires an external field to generate turbulences for the mixing process (Pawinanto et al. 2019). With external fields and the corresponding integrated components, the structures of active micromixers are often complicated and require complex fabrication processes. For passive micromixers, it does not require external energy, the mixing process relies entirely on diffusion or chaotic advection. Passive mixers can be further categorized by the arrangement of the mixed phases: Parallel lamination, serial lamination, injection, chaotic advection, and droplet.

One of the similarities between the micro-nanofilter and micromixer are that both have micropillars as the essential components in both devices (Ali et al. 2018; Bertana et al. 2019). In microfiltration device, the function of these micropillars are to traps larger particles from small particles and separate them from mixing together back, as shown in Figure 1. In micromixing device, the function of these micropillars are to create turbulences flow inside the micromixer channel for rapid and uniform mixing process.

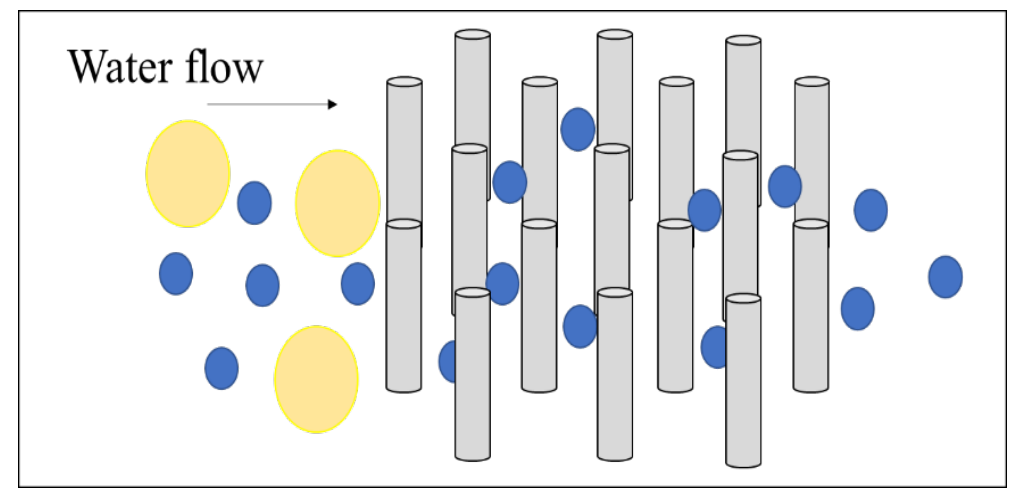

FIGURE 1. 3D schematic images of pillars inside the microfilter

The current method used to fabricate the micropillars is by subtractive process which involves the removal of some material from the workpiece in order to produce a specific geometry at a definite degree of accuracy and surface quality. The primary method producing micropillars from bulk materials is Focused Ion Beam (FIB) Milling. Instead of a focused beam of electrons, FIB setups utilize a high-energy gallium $(\mathrm{Ga})$ ion beam to sputter the uppermost atomic layers of a material and facilitate ultra-precise sample machining on the sub-microscale. This process has become popularised in recent decades due to its outstanding accuracy in semiconductor etching applications (Alemnis 2020). Producing these micropillar comes with a great cost and time consuming. The process requires a clean room laboratory and also produced unwanted waste. Although it promised a good result, this process could be optimised with the current available technology which use 3D printer.
Nowadays, 3D printing has emerged as an intriguing method for producing microfluidic devices due to its simple operation and fast design workflow. The technique has been implemented for various micro-devices including filter and mixer devices (Bazaz et al. 2020; Hu et al. 2020; Vasilescu et al. 2020). Direct 3D printing is a rapid process for prototyping, making multiple copies of device, cheaper, and more reliable (Sochol et al. 2018). With the improvements in $3 \mathrm{D}$ printing technologies, complex small devices can be fabricated via single-step, rapid, and cost-effective protocols as a promising alternative to the conventional microfabrication process that requires expensive facilities, such as cleanroom. Of all types of 3D printer, the Digital Light Process (DLP) is the most suitable and reliable technique that can produce the smallest dimension of membrane compared to other types of 3D printer (Bertana et al. 2019; Waheed et al. 2016). With this $3 \mathrm{D}$ printing process, the fabrication becomes easier and this technology will be more accessible to other 
researchers. In this paper, we report the process fabrication of micropillars by using a DLP 3D Printer that will be an alternative way for creating rapid lab on chip system in an artificial kidney application.

\section{MATERIALS AND METHODS}

In this work, we fabricated the arrays of micropillars using 3D printing technique called DLP. These pillars are used to trap larger molecules and separate them throughout the filtration process or to create turbulences inside the microfluidic chamber through fluid diffusion to mix two different fluidic samples. Figure 2 shows the schematic of the studied microfluidic systems that includes the inlet, outlet, a microchannel and arrays of pillars.

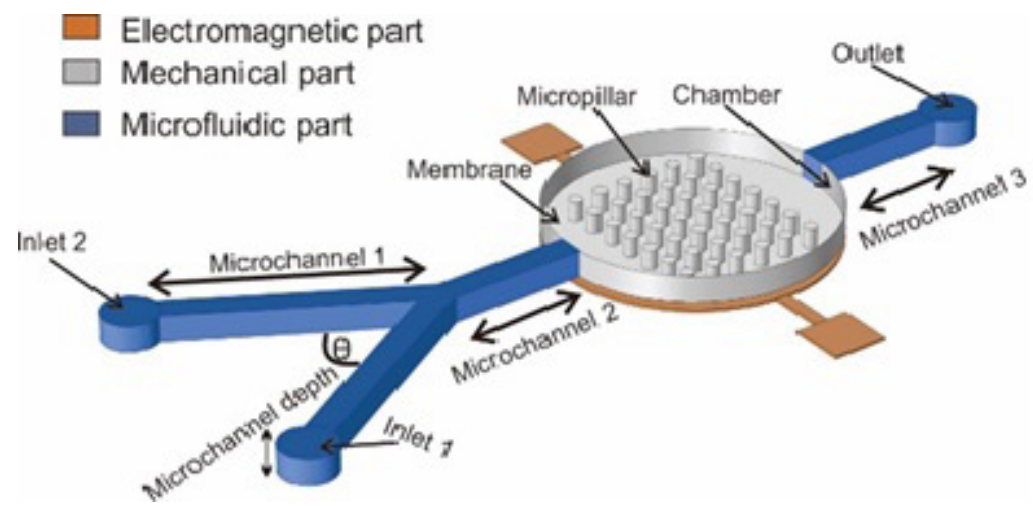

FIGURE 2. A schematic diagram of microfluidic system

The process for creating the micro structures started with a design process of the pillars, chamber, channel shape, 3D printing, and post processing of the cured resin. In this experiment, the devices were designed using the computer-aided-design (CAD) program called SolidWorks. All measurements need to be considered before being drawn on CAD software due to the limitations of the 3D printer such as size of the channel, pillars and the $\mathrm{X}, \mathrm{Y}-$ resolution of the device. All the dimensions are then inserted into the CAD program. Next, the CAD software converted the drawing into stereolithography (stl) file so that the 3D printer slicer software can exported the file to the $3 \mathrm{D}$ printer. In this research, we were using Creality LD-001 3D printer to test our experiments. The limitations for the 3D printer are stated in Table 1. All the dimensions for microfluidic device are stated in Table 2.

TABLE 1. Limitations for Creality LD-001 3D printer

\begin{tabular}{cc}
\hline Parameter & Limitation \\
\hline X, Y - Resolution & $47 \mu \mathrm{m}$ \\
Z axis accuracy & $20 \mu \mathrm{m}$ \\
Print speed & $20 \mathrm{~mm} / \mathrm{hour}$ \\
Moulding size & $120 \times 70 \times 120 \mathrm{~mm}$ \\
\hline
\end{tabular}

TABLE 2. Fixed dimensions for microfluidic device

\begin{tabular}{cc}
\hline Part & Dimension $(\mu \mathrm{m})$ \\
\hline Pillar height & 2500 \\
Microchannel width & 1000 \\
Microchannel length & 10000 \\
Chamber radius & 10000 \\
Inlet/Outlet radius & 5000 \\
\hline
\end{tabular}


There are several types of resin including tough, elastic, clear, nylon-like, and castable resin. They have different monomers and oligomers molecules which lead to different end product. In this experiment, the material used for printing is called clear resin. During printing, the Creality LD-001 cured the photosensitive resin from liquid state to solid using digital-light-processing mechanism. DLP uses an arc lamp with a liquid crystal display panel. The build platform is initially positioned in the vat with liquid photopolymer resin, at a distance of one-layer, $20 \mu \mathrm{m}$ height from the surface of the liquid resin. Then, the UV light creates the next layer by curing the resin. After curing a layer, the build platform moves up and the resin recoats the build platform surface with a new layer. This process is repeated until the device is completed. The schematic processes of $3 \mathrm{D}$ printing are shown in Figure 3.
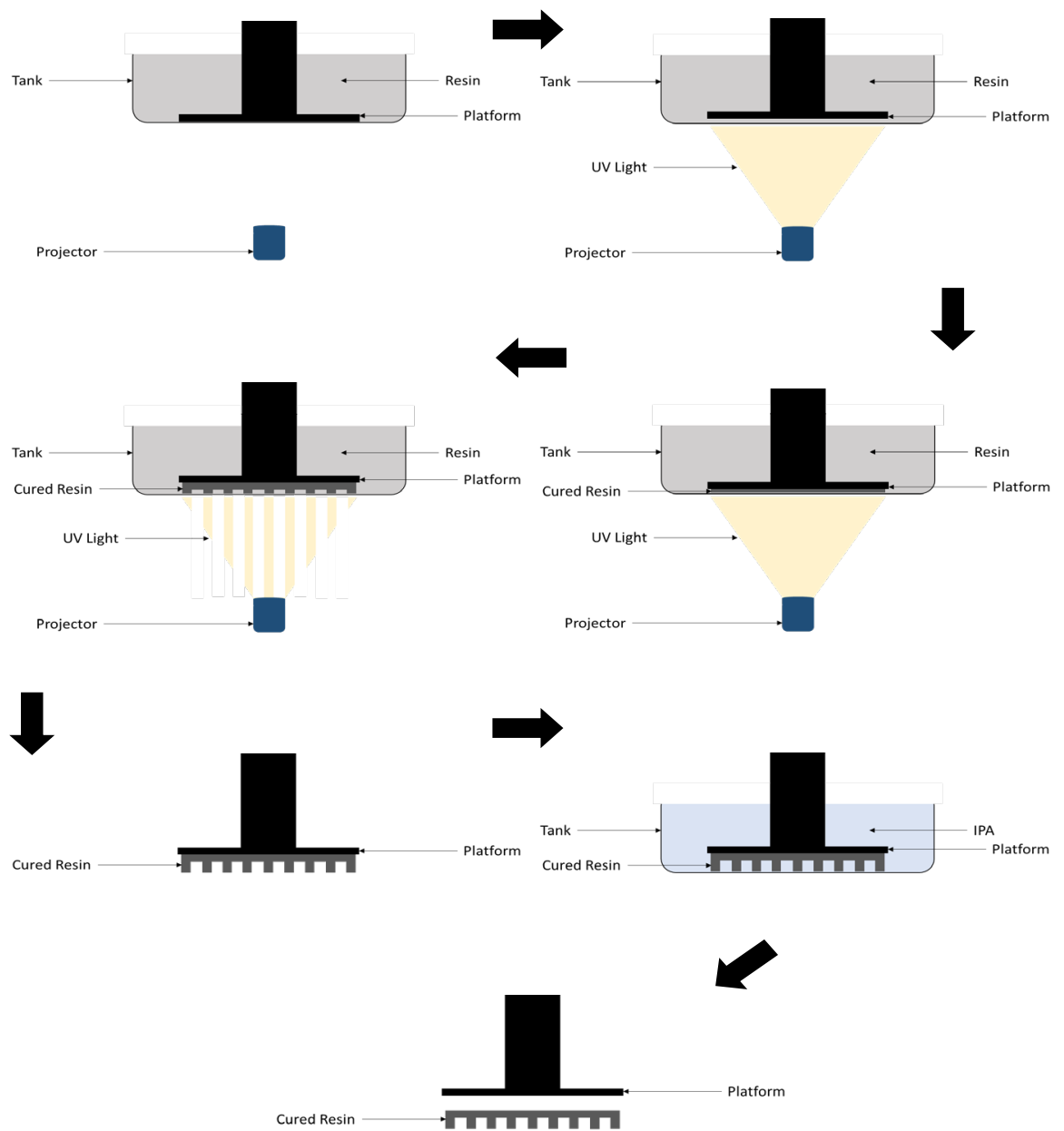

FIGURE 3. Schematic process of 3D printing

Postprocessing is needed in order to achieve optimum thermo-mechanical properties. The postprocessing is quite easy by dipping the parts into isopropyl alcohol for a few minutes to remove the excess resin that sticks around the printed parts. Later, the device is then cured under UV curing lamp for a few minutes to strengthen the layers and make it became more solid. Time of the curing also needs to be optimised according to the thickness of the membrane so that the device will not getting sunburned or damaged. After completing the printing and postprocessing process, the sample is ready for the characterisation process. Figure 4 shows the fabricated microfluidic system after the printing process. 


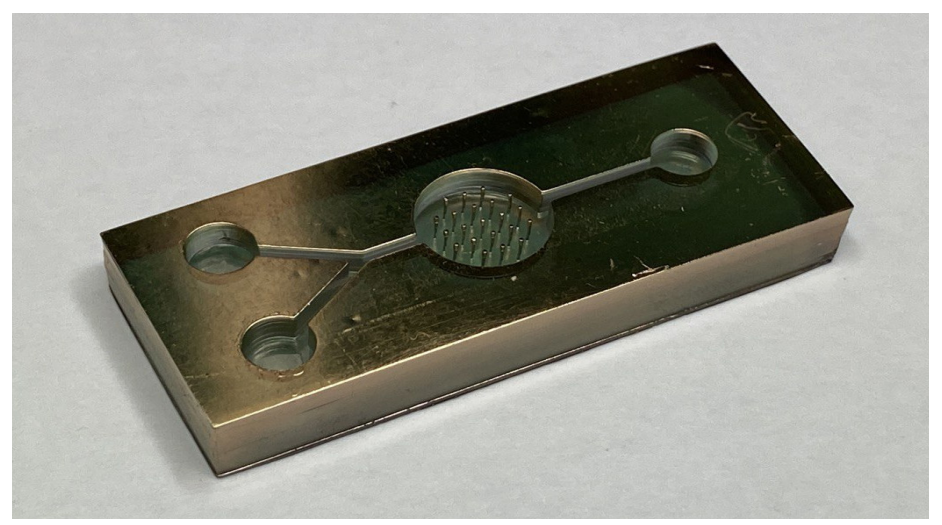

FIGURE 4. Printed device produced by 3D printer

\section{RESULTS AND DISCUSSION}

Polymers are generally very sensitive materials. The electron beam can damage them, especially when a very high voltage is applied. The electron emitted by the microscope can interact with the delicate intermolecular bonds and break them. Therefore, the device needs to be coated using a sputter coating device that can cover the material with a thin layer of conductive material. In this experiment, the material that is used to coat the device is gold. This will make it suitable for Scanning Electron Microscope (SEM) analysis without meaningfully altering the structure of the sample. From the Figure 5 , we can see that the $3 \mathrm{D}$ printer system can produce micropillars structure properly with a high aspect ratio of maximum 7.5.

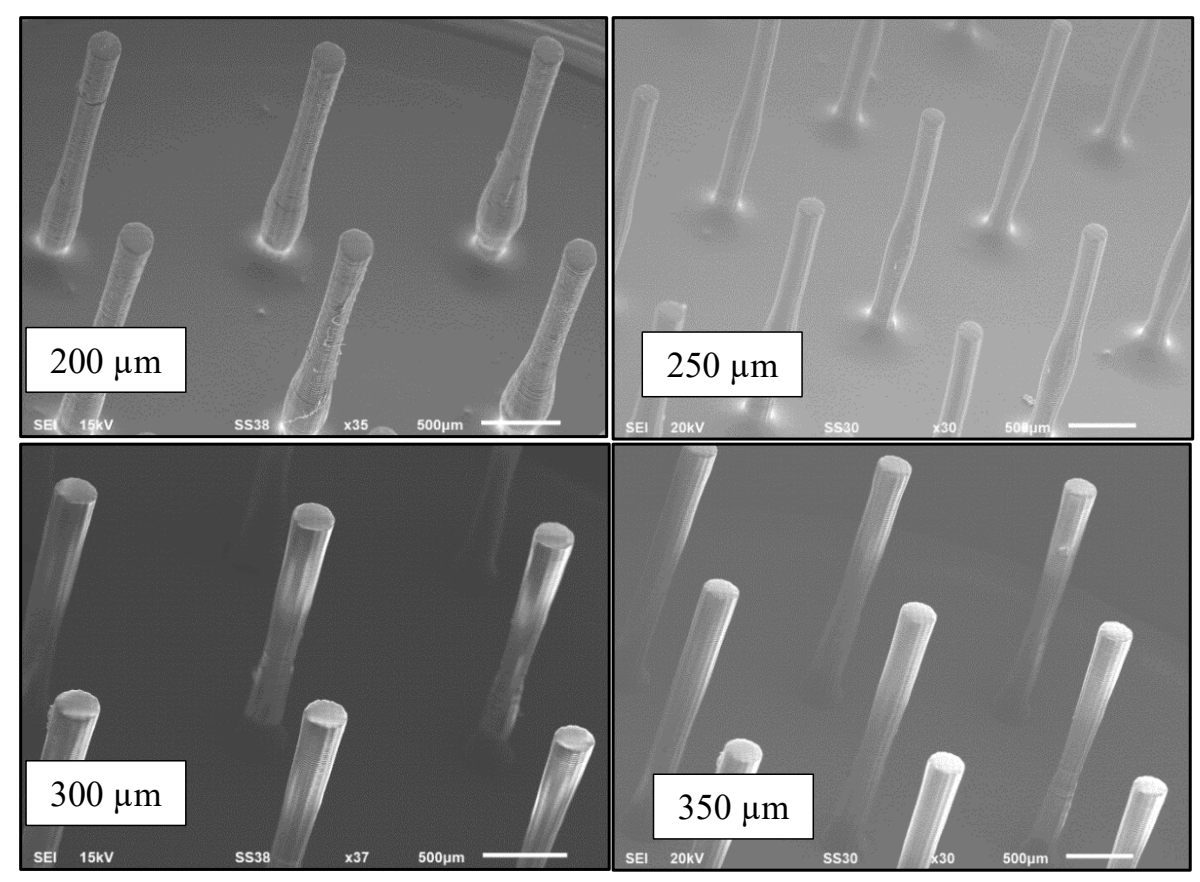

FIGURE 5. SEM images of micropillars with different sizes

Printing using the DLP was most difficult to optimize compared to other types of $3 \mathrm{D}$ printer. Variables in fabrication conditions (exposure times, position, slicing software, resin age) all impacted on the outcome as shown in Table 3. 
TABLE 3. Data for micropillars with size 200 - $400 \mu \mathrm{m}$ with different distance between pillars

\begin{tabular}{cccc}
\hline $\begin{array}{c}\text { References for size of pillars } \\
(\mu \mathrm{m})\end{array}$ & 500 & 700 & Distance between pillars $(\mu \mathrm{m})$ \\
\hline 200 & 172.23 & 173.33 & 1800 \\
250 & 227.27 & 238.65 & 245.64 \\
300 & 275.71 & 286.67 & 296.3 \\
350 & 343.43 & 347.36 & 349.61 \\
400 & 381.59 & 394.82 & 399.85 \\
\hline
\end{tabular}

The obtained data were interpreted into a graph as shown in Figure 6 to evaluate the result from the experiment. It can be seen clearly that the most approximate sample size for micropillars was $400 \mu \mathrm{m}$. From the figure, we can see that the graph is going towards the reference line as the size of pillars increases. It can be seen that the pillar distance affects to the quality of the printed pillar. If we put the distance between the pillars of $1 \mathrm{~mm}$, the pillar size can be formed matched to the reference size.

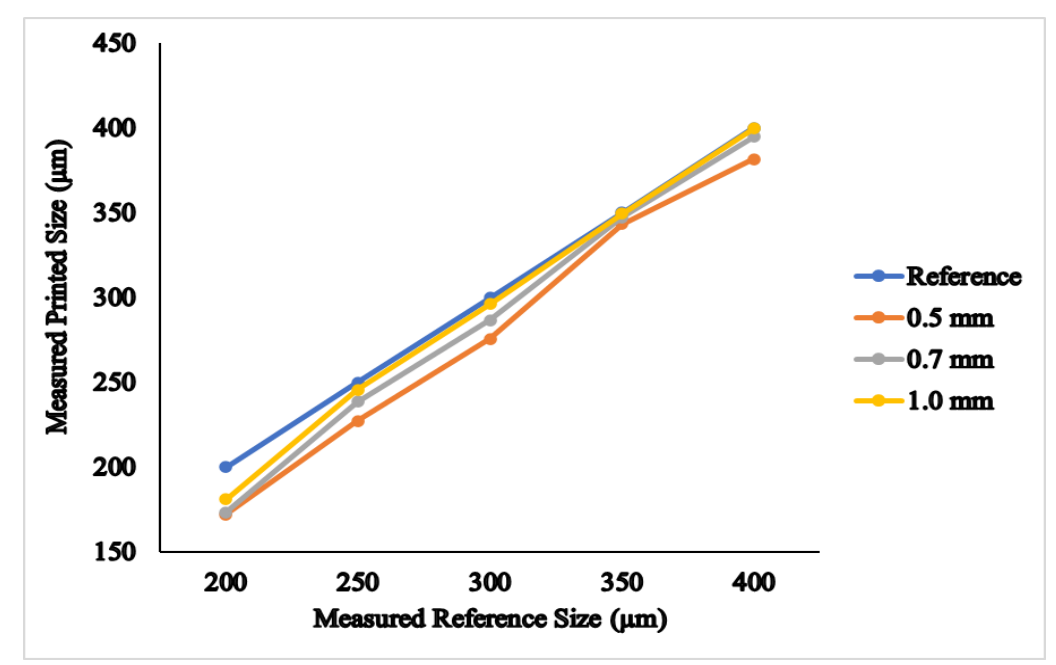

FIGURE 6. Micropillars size formed by using 3D printer for various pillar distance

In Figure 7, we can see that all samples with diameters larger than $200 \mu \mathrm{m}$ having good accuracy can be obtained. We can also conclude that, as the size of pillars increases, the higher percentage of successful formed pillars could be achieved.

Analysis on the resin condition for the printing result of the micropillars observed by SEM is shown in Figure 8. It can be seen that the micropillars printed using fresh resin are well formed better compared to that printed using aged or used resin. This is probably caused by the polymerization of the material when multi expose of the resin was carried out that affect to the pattern creation of the pillar. Another possible explanation is that the UV curing resin should be cured by exposing ultraviolet with a wavelength of $200-400 \mathrm{~nm}$. For our DLP machine, the wavelength of ultraviolet exposing to the resin is $405 \mathrm{~nm}$. This cause the lack on the optical energy absorption of the material. 


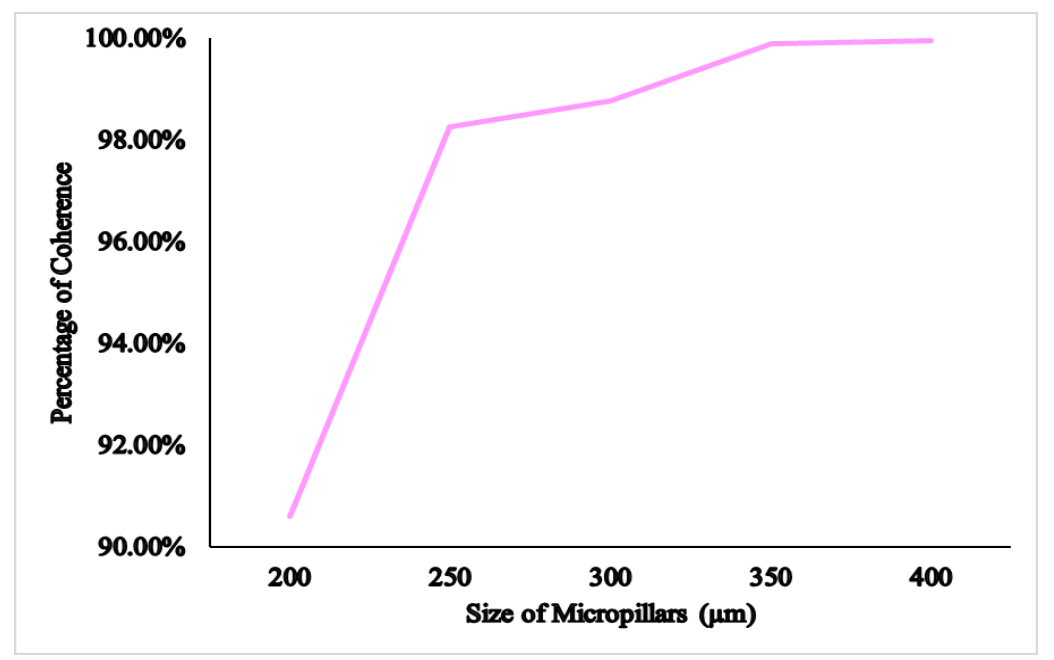

FIGURE 7. Percentage of coherence for micropillars size

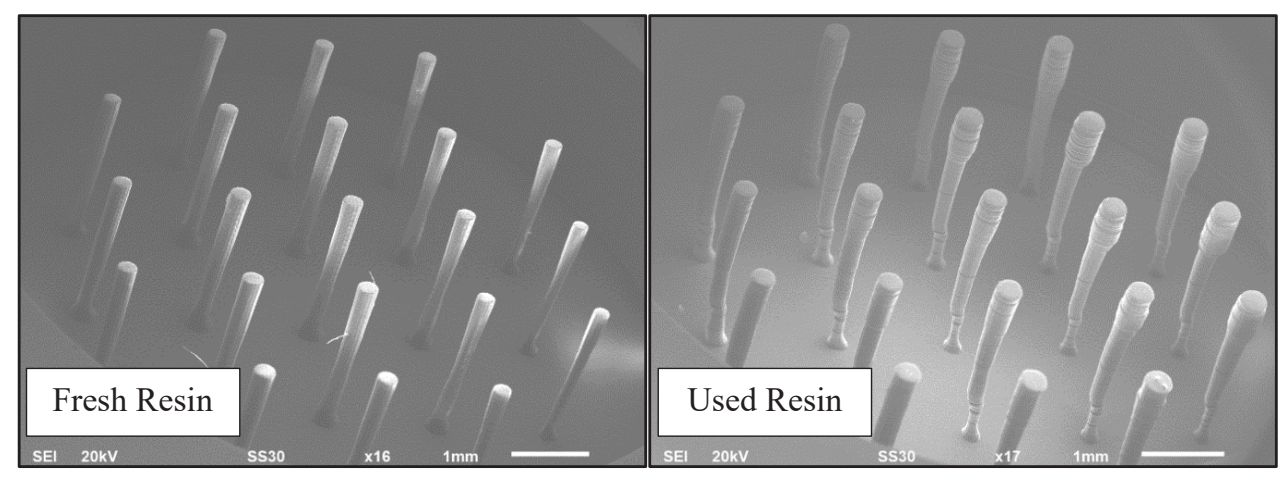

FIGURE 8. SEM images of micropillars by using fresh (left) and used resin (right)

Although some of the pillars are not formed straight, this proved that a $3 \mathrm{D}$ printer could produce a high aspect ratio for micron size. The DLP printer was the only printer to produce channels slightly smaller than the design $(26 \pm 20 \mu \mathrm{m})$ and was the highest in accuracy and precision compared with another $3 \mathrm{D}$ printer. The superior accuracy and precision of the DLP makes this the better choice for microfabrication, however it cannot match yet zzlithography processes (Sochol et al. 2018).

\section{CONCLUSION}

A $3 \mathrm{D}$ printing technology for the rapid prototyping of microfilter is presented. In this study, the creation of arrays of pillars were focused. Micropillars having the diameter of 200 to $400 \mu \mathrm{m}$ can be produced properly with consideration of exposure times, position, slicing software, and resin age. The 3D printing file was prepared by using slicer software where the setting was applied on the model for a layer height of $20 \mu \mathrm{m}$ with exposure time of $8 \mathrm{~s}$ for each layer. Our preliminary experiment showed that the DLP printer was able to produce arrays of micropillars. As the size of pillars increases, the percentage of successful pillars formed could achieved $100 \%$ accuracy. The process is fast, versatile and efficient, which can fabricate virtually any shape and geometry enabling a rapid development of microfluidic device for biomedical application.

\section{ACKNOWLEDGEMENTS}

This research is supported by HiCoE project under AKU254 and PRGS/1/2017/TK05/UKM/02/1: MEMS 
for Artificial Kidney funded by the Ministry of Higher Education (MOHE), Malaysia.

\section{REFERENCES}

Alemnis, A.G. 2020. What are Micropillars and How are They Produced? https://www.azom.com/article. aspx?ArticleID $=18867$.

Ali, W.A.F.W., Hamzah, A.A., Mustafa, K.A., Majlis, B.Y. \& Yunas, J. 2018. Numerical study of zigzag micro mixer with 3D channel dimension. 2018 IEEE International Conference on Semiconductor Electronics (ICSE). pp. 117-120.

Ali, W.A.F.W., Yunas, J., Hamzah, A.A. \& Majlis, B.Y. 2017. Numerical study of laminar flow in pillared-micro channel. 2017 IEEE Regional Symposium on Micro and Nanoelectronics (RSM). pp. 71-74.

Bazaz, S.R., Rouhi, O., Raoufi, M.A., Ejeian, F., Asadnia, M., Jin, D. \& Warkiani, M.E. 2020.3D printing of inertial microfluidic devices. Scientific Reports 10(1): 1-14.

Bertana, V., De Pasquale, G., Ferrero, S., Scaltrito, L., Catania, F., Nicosia, C., Marasso, S.L., Cocuzza, M. \& Perrucci, F. 2019. $3 \mathrm{D}$ printing with the commercial UV-curable standard blend resin: Optimized process parameters towards the fabrication of tiny functional parts. Polymers 11(2): 292.

Buyong, M.R., Yunas, J., Hamzah, A.A., Majlis, B.Y., Larki, F. \& Abd Aziz, N. 2015. Design, fabrication and characterization of dielectrophoretic microelectrode array for particle capture. Microelectronics International 32(2): 96-102.

Hamzah, A.A., Abidin, H.E.Z., Majlis, B.Y., Nor, M.M., Ismardi, A., Sugandi, G., Tiong, T.Y., Dee, C.F. \& Yunas, J. 2013. Electrochemically deposited and etched membranes with precisely sized micropores for biological fluids microfiltration. J. Micromech. Microeng. 23: 074007.

Hu, Y., Yuan, H., Liu, S., Ni, J., Lao, Z., Xin, C., Pan, D., Zhang, Y., Zhu, W., Li, J. \& Wu, D. 2020. Chiral assemblies of laserprinted micropillars directed by asymmetrical capillary force. Advanced Materials 32(31): 2002356.

Mustafa, K.A., Majlis, B.Y., Yunas, J. \& Hamzah, A.A. 2019. Fabrication of micromachined uniform microtrench arrays for silicon based filtration membrane. Sains Malaysiana 48(6): 1171-1178.

Mustafa, K.A., Yunas, J., Hamzah, A.A. \& Majlis, B.Y. 2017. Application of BOE and $\mathrm{KOH}+\mathrm{IPA}$ for fabrication of smooth nanopore membrane surface for artificial kidney. 2017 IEEE Regional Symposium on Micro and Nanoelectronics (RSM). pp. 18-21.
Pawinanto, R.E., Yunas, J. \& Hashim, A.M. 2019. Design optimization of active microfluidic mixer incorporating micropillar on flexible membrane. Microsystem Technologies 25(4): 1203-1209.

Shaaban, A.M.F., Hafez, A.I., Abdel-Fatah, M.A., AbdelMonem, N.M. \& Mahmoud, M.H. 2016. Process engineering optimization of nanofiltration unit for the treatment of textile plant effluent in view of solution diffusion model. Egyptian Journal of Petroleum 25(1): 79-90.

Sochol, R.D., Sweet, E., Glick, C.C., Wu, S.Y., Yang, C., Restaino, M. \& Lin, L. 2018. 3D printed microfluidics and microelectronics. Microelectronic Engineering 189: 52-68.

Vasilescu, S.A., Bazaz, S.R., Jin, D., Shimoni, O. \& Warkiani, M.E. 2020. 3D printing enables the rapid prototyping of modular microfluidic devices for particle conjugation. Applied Materials Today 20: 100726.

Waheed, S., Cabot, J.M., Macdonald, N.P., Lewis, T., Guijt, R.M., Paull, B. \& Breadmore, M.C. 2016. 3D printed microfluidic devices: Enablers and barriers. Lab on a Chip 16(11): 19932013.

Yaakub, T.N.T., Yunas, J., Latif, R., Hamzah, A.A., Wee, M.F.M.R. \& Majlis, B.Y. 2018. Surface modification of electroosmotic silicon microchannel using thermal dry oxidation. Micromachines 9(5): 222.

Yilmaz, B. \& Yilmaz, F. 2018. Lab-on-a-chip technology and its applications. In Omics Technologies and Bio-Engineering, edited by Barh, D. \& Azevedo, V. London: Academic Press. pp. 145-153.

Yunas, J., Mulyanti, B., Hamidah, I., Said, M.M., Pawinanto, R.E., Ali, W.A.F.W., Subandi, A., Hamzah, A.A., Latif, R. \& Majlis, B.Y. 2020. Polymer-based MEMS electromagnetic actuator for biomedical application: A review. Polymers 12(5): 1184.

Institute of Microengineering and Nanoelectronics (IMEN) Universiti Kebangsaan Malaysia 43600 UKM Bangi, Selangor Darul Ehsan Malaysia

*Corresponding author; email: jumrilyunas@ukm.edu.my

Received: 18 August 2020

Accepted: 27 August 2020 